\title{
A narancsborok nyújtotta lehetôségek a szlovén, a horvát és az olasz gasztronómiai turizmusban
}

\author{
Szerzők: Bene Zsuzsannaํ - Piskóti István²
}

Az UNESCO definiálásában a mediterrán étrend, mint világörökség, a növénytermesztést, a betakaritást, a halászatot, az állattenyésztést, a tartósítást, a feldolgozást, az elkészitést és kiemelten az ételek elkészítését magába foglaló készségek, tudás, valamint hagyományok összessége. Hívószavai az egészség, a helyi termékek, a tradíció, az élet élvezete. A narancsborok olyan naturalista természetes fehérborok, melyeket héjon erjesztenek több ezer éves hagyományokon alapuló eljárással. Ezek a borok kedvezó élettani hatású vegyületeket (polifenolok, katechinek, antioxidánsok) tartalmaznak, készítésükhöz legtöbbször ökológiai gazdálkodásból származó alapanyagot használnak, illetve mellőznek minden kémiai segédanyag használatot és kén-dioxidot egyáltalán nem vagy csak kismértékben alkalmaznak. Számos országban készitenek ilyen borokat, de leginkább a mediterrán térség borászataiban, kiemelten Szlovéniában, Horvátországban és Olaszországban lehet találkozni velük. Munkánk során egyrészt azt vizsgáltuk, hogy ez a bortípus önmagában mennyire képes turisztikai vonzerôként funkcionálni, így mozdítva elő a gasztronómiai turizmust ezekben az országokban, másrészt azt, hogy milyen helyet foglal el a mediterrán gasztronómiában, illetve lehet-e és érdemes-e a narancsborra turizmust építeni.

Kulcsszavak: mediterrán étrend, narancsbor, gasztronómiai turizmus.

\section{Bevezetés}

Az európai gasztronómiai örökségről szóló európai parlamenti indítvány ${ }^{3}$ szerint kiemelkedő kulturális szempont, hogy a gasztronómia három eleme - az egészség, az étkezési szokások és az öröm -, a társasági élet fontos szereplői és a kultúrák találkozása összehozza a különböző országok lakóit. Alapvető fontosságú továbbá a helyi termékek népszerûsítése és az egyes országok konyhamúvészeti sajátosságainak megőrzése. A gasztronómia és az idegenforgalom kölcsönhatása kedvezően hat a turizmus élénkítésére. A minőségi helyi termelésnek a szakértelmen, a gondosságon és a hagyományokon kell alapulnia, hogy fennmaradhasson az európai gasztronómia sokszínúsége, hírneve, kulturális gazdagsága.

A mediterrán étkezési szokások nem csupán egy táplálkozási mód, hanem eszmék megtestesülése is egyben. Középpontjában a természetesség és az egészség áll, ami a héjon erjesztett fehérborok, az úgynevezett narancsborok fontos jellemzője is.

\footnotetext{
egyetemi docens, Miskolci Egyetem, bene.zsuzsanna@uni-miskolc.hu 2 egyetemi tanár, Miskolci Egyetem, piskoti@uni-miskolc.hu

${ }^{3}$ 2013/2181(INI): https://oeil.secure.europarl.europa.eu/oeil/popups/ficheprocedure.do?lang=en\&reference $=2013 / 2181$ (INI)
}

A Földközi-tenger országaiban lévő borászatok készítik a legtöbb narancsbort a világon (BONNÉ 2018), amelynek készítési eljárása az ósi grúz módszeren alapul. Ez a bor szólőből készül, nem a mediterrán gyümölcsból, viszont színe és illata a narancsra emlékeztet. Száraz fehérborokról van szó, rendkívül egyedi ízvilággal és megjelenéssel.

Munkánk során kerestük azokat a pozícionálási tényezőket, amelyek megerősítik a héjon erjesztett fehérborok helyét a mediterrán étrendben, amelynek része a mérsékelt borfogyasztás. Vizsgáltuk, hogy egy új kulináris élmény megteremtésével ezek a borok képesek-e előmozdítani, hogy több turista válassza az adott vendéglátóhelyet, vagy utazzon el az adott desztinációba a bor híre és a készítési eljárás iránti kíváncsiság miatt.

\section{Szakirodalmi áttekintés}

\subsection{A GASZTRONÓMIAI TURIZMUS ÉS TURISZTIKAI TERMÉKEINEK SAJÁTOSSÁGAI}

A gasztronómiai turizmus meghatározásakor olyan utazásokra kell fókuszálnunk, amelyeknek elsődleges célja a különböző étel- és italféleségek előállítási helyének felkeresése, kulináris élmények szerzése az adott, gasztronómiájáról híres desztinációba való ellátogatáskor vagy részvétel a gasztronómiai termék köré szerveződő gaszt- 
Lektorált tanulmányok

ronómiai fesztiválon (HJALAGER-RICHARDS 2001). Fontos szempont a gasztronómiai élmény természete és minősége. A gasztronómiai élmény egy autentikus, emlékezetes, étellel vagy itallal kapcsolatos tevékenység, mely magában foglalja a háttérfolyamatok, az elóállítás megfigyelését, a kulturális vagy regionális jellegzetességeket, illetve gyakran az ezekben való aktív közremúködést, miközben az ember ünnepélyesen részesül az ételből vagy italból (WILLIAMS et al. 2013). Motivációt jelenthet még véleményformáló gasztronómiai versenyen (Bocuse d'Or) nézőként való részvétel (MTÜ 2019).

A gasztronómiai turizmus szereplói olyan turisták, akik egy adott desztináció konyhamúvészetét szeretnék megismerni és kipróbálni (UNWTO 2012). A gasztronómiai turizmust gyakran a kulturális turizmus részeként említik, azonban nemzetgazdasági jelentôségét tekintve ma már önálló turizmusformaként is megjelenik. A gasztronómiai turizmus altermékei:

- éttermi turizmus: amikor azokat a vendéglátóhelyeket keresik fel a turisták, amelyek vagy rendelkeznek véleményformáló éttermi minősítéssel (Gault-Millau, Michelin-Guide), vagy trendkövetőek, mint például a Paladar típusú lakáséttermek vagy a pop-up éttermek;

- termelói turizmus: termelólátogatás, termelői piacok, falusi vendégasztalok;

- bor- és borászat turizmus: nemcsak a borhoz, hanem magához a borászhoz és a borászathoz köthetố turizmus;

- bor és egyéb gasztronómiai termék fókuszú tematikus útvonalak;

- romkocsmaturizmus (MTÜ 2019).

A gasztronómiai turizmus típusainak meghatározásakor az egyes élelmiszercsoportok állnak a fókuszban, így megkülönböztetünk: bor, sör, whisky, szaké, cider, pezsgó, kávé, olaj, tea, ecet, sajt, sonka, szarvasgomba, csokoládé, szilva és marcipán altípusokat (KÖNYVES-VARGÁNÉ 2015).

Nagyon fontos szerepük van az innováció révén létrejött gasztronómiai termékeknek, mert újabb lehetôséget kínálnak az érdeklódés felkeltésére. Az ezekhez az altípusokhoz kötődő utazások során a gasztroturisták megismerik az adott étel- és italtípus termőhelyét, betekintést nyernek a készítési eljárások fortélyaiba, és elsajátítják az étel-ital párosításokhoz kötődő kulináris ismereteket. Egészen más élményben részesül így az utazó, mintha ezeket az élelmiszereket nem az előállítási helyén fogyasztaná el, hanem a saját lakóhelyén megvásárolható termékek közül választana és az otthonában kóstolna. Nagyon fon- tos, hogy az adott desztinációnak legyen olyan gasztronómiai vonzereje, ami elsődleges utazási motivációként tud megjelenni. A hagyományos helyi specialitások, az eredetvédett élelmiszerek kiemelkedő jelentóséggel bírnak a gasztronómiai turizmusban, mert az autentikusság és a hitelesség, a termelôvel való személyes kontaktus megteremti az utazási szándék megfogalmazódását, ezáltal növelve az adott desztináció iránti érdeklődést.

A gasztronómiai turizmusnak öt fő motivációja létezik (TIKKANEN 2007):

- maga az étel a fő attrakció,

- az élelmiszerek a turisztikai termékek, melyeket a turisták fogyasztanak és vásárolnak,

- a gasztronómiai élmények értékelése és keresése,

- az étel, mint kulturális jelenség,

- turizmus és élelmiszer-elóállítás kapcsolata.

Egy adott desztináció gasztronómiai egyedisége több dolgot foglal magába. Ide tartozik a különleges ízvilág megléte, az egyedülálló receptek, a sajátos konyhatechnológiai eljárások, az adott desztinációban megjelenő bor-étel párosítások, a régi és az új stílusok találkozása és az éghajlati övezetek szerinti jellegzetességek (HARRINGTON 2005). Ezt az egyediséget befolyásolja a kultúra és a környezeti tényezók, amelyek együttes megjelenését az úgynevezett gasztronómiai identitás modell mutatja (1. ábra).

1. ábra

A gasztronómiai identitás modell

\begin{tabular}{|c|c|c|}
\hline Kultúra & Gasztronómiai identitás & Környezeti tényezök \\
\hline Történelem & Ízek & Földrajz \\
\hline Vallás & Receptek & Éghajlat \\
\hline Hagyományok & Konyhatechnológiák & Mikroklíma \\
\hline Lehetőségek & Bor-étel párosítások & Helyi alapanyagok \\
\hline Innovációk & $\begin{array}{l}\text { Régi és új stílusok } \\
\text { találkozása }\end{array}$ & $\begin{array}{l}\text { Lehetőségek új } \\
\text { termékek elóállitására }\end{array}$ \\
\hline & $\begin{array}{l}\text { Éghajlati övezetek szerinti } \\
\text { sajátosságok }\end{array}$ & \\
\hline
\end{tabular}

Forrás: saját szerkesztés HARRINGTON (2005) alapján

Nagyon fontos, hogy legyen egy egyedi megkülönböztető jegy. A minőségi helyi alapanyagokra kell hangsúlyt fektetni, jelenjen meg az úgynevezett retroinnováció, azaz kerüljön előtérbe a hagyományokon alapuló modernitás, és legyen egy story a háttérben, egy történet, egy legenda, egy monda, egy misztikum, amelynek desztinációba csalogató hatása van (GUZEL-APAYDIN 2017). A gasztronómia az éló kultúra része, növeli az adott desztináció vonzerejét, fenntartható és erôsíti a helyi identitást (COPPOLA 2016). 
A gasztronómiai turizmus legfontosabb jellemzői (UNWTO 2018):

- a gasztronómia értéke a konyhamúvészet-termóhely-termék háromszögben rejlik, ennek a három tényezőnek az együttes megjelenésére épül;

- az adott termóhelyek lokálpatrióta lakossága közvetíti a kulináris hagyományokat;

- a helyi közösségek létezésének és múködésének hangsúlyozása és elősegítése, hogy fennmaradjanak az autentikus termőhelyek;

- nemcsak betekintést ad a helyi közösség életébe, hanem a közös étel-, italkészítés élményszerzését nyújtja;

- a digitális ismeretterjesztés révén, ahol az egyes desztinációk gasztronómiai értékei iránti kíváncsiság felkeltésére építenek, növelhetó a gasztroturisták száma;

- multikulturalitás: a globalizációnak együtt kell járnia a helyi termékek és konyhamúvészetek megórzésével, a hagyományokat nem elfelejteni kell, hanem újragondolni és teret engedni az innovációnak;

- már kisgyermekkorban el kell kezdeni az adott nemzet gasztronómiai értékeinek megismertetését, hogy az beépülhessen a nemzeti öntudatba.

A gasztronómiai turizmus növekedését befolyásoló öt fő trend (BARCELONA FIELD STUDIES CENTRE 2012):

- trading up - a fogyasztók jövedelmük nagyobb hányadát költik diszkrecionális vásárlásokra, ha a termék, a szolgáltatás vagy az élmény valamilyen vágyat elégít ki, és kevesebbet, ha pusztán fizikai vonatkozásban van szükség rájuk;

- demográfiai és háztartásbeli változások - a korosodó népesség és az életmódbeli változások hatására megnőtt az igény a nem otthoni étkezések és a gasztronómiai turisztikai lehetőségek iránt;

- a McDonaldizáció elutasítása - a turisták az unalmasnak és egyéniség nélkülinek tartott olcsó tömegélelmiszerek helyett a desztináció autentikusságát hordozó helyi, friss ételeket keresik;

- a multikulturális fogyasztók számának növekedése - főként a globalizáció, az internet, a nemzetközi utazások számának rohamos fejlődése eredményezte;

- ünnepelt séfek és média - a fózőmúsorok, a TV csatornák és a magazinok egymással versengó celebeket és szakértőket termeltek ki.

\subsection{A SZLOVÉN, A HORVÁT ÉS AZ OLASZ MEDITERRÁNEUM ÉS GASZTRONÓMIAI ÉRTÉKEI}

A Mediterráneum a Földközi-tenger országait foglalja magába. Szlovénia, Horvátország és Olaszország az északi térséghez tartozik. Az itt élő népek kultúrája, hagyományai, szokásai, vallása és életmódja országonként különböző. Más összetételú a termőtalaj, különbségek vannak a növénytermesztés, az állattenyésztés és az ételkészítés technikái között, de eltérnek a táplálkozási szokások is. Nemzetenként, sőt akár országon belül is vannak különbségek.

Lévén az étkezési kultúra és a szokások között szoros kapcsolat áll fenn, Olaszország, Spanyolország, Görögország és Marokkó kezdeményezte ennek deklarálását, amelyre 2010-ben és 2013-ban került sor a mediterrán táplálkozás szellemi világörökséggé nyilvánításával. Így a Földközi-tenger országai számára létrejött egy megkülönböztetó, jelzésértékú szerepkör.

Az UNWTO (2018) jelentése szerint Európa az elmúlt 10 évben a világ leglátogatottabb desztinációjává nőtte ki magát. 2017-ben 682 millió turista látogatott ide, ami 8\%-os növekedést, vagyis 52 millióval több turistát jelent az előző évhez képest. Az alrégiók tekintetében Dél-Európának, a mediterrán térségnek van vezetó szerepe (2. ábra). A térségben tapasztalható növekedés több tényezőre vezethető vissza: a termékközpontúságra való törekvésre, az együttmúködési szándékra, a kommunikáció és a minőség fejlesztésére, valamint a fenntartható élelmiszertermelés iránti figyelemre.

\section{2. ábra}

A mediterrán térségbe látogató turisták száma (millió fó/év)

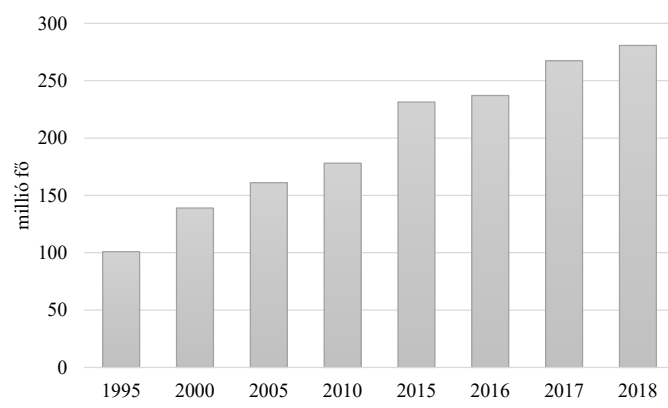

Forrás: saját szerkesztés UNWTO (2018) alapján

\subsubsection{A mediterrán étrend, mint szellemi világörökség}

A térség változatos és színes étkezési kultúrájában a mediterrán táplálkozás jellegzetes és meghatározó elemei mindenhol megtalálhatóak (SZENDE 
Lektorált tanulmányok

2018). Ancel Keys amerikai táplálkozástudós nevéhez fúződik a mediterrán étrend elnevezés, aki tudományosan bizonyította ennek a táplálkozási elvnek az egészségre gyakorolt jótékony hatását. 1954-tól kezdve 7 országban (Japán, az akkori Jugoszlávia, Görögország, Amerikai Egyesült Államok, Hollandia, Olaszország, Finnország) 25 évig követte nyomon munkatársaival a szív- és érrendszeri megbetegedések előfordulását és az ezekre visszavezethető halálozások gyakoriságát. Tanulmányaik alapján a mediterrán országokban szignifikánsan kevesebb volt a kardiovaszkuláris megbetegedések száma ${ }^{4}$. Az egészség és a hoszszabb várható élettartam fontos hívószavai ennek az étkezési kultúrának, a hozzá kapcsolódó igényt a különböző gyorsétkezési trendek nem tudják kielégíteni. A mediterrán konyha képviselői azt az alapanyagot fogyasztják, amely frissen a rendelkezésükre áll. A háziasszonyok nagy része kistermelóktôl vásárol a piacon, és azokkal a fúszernövényekkel ízesít, amelyeket saját maga termel a fúszerkertjében.

További fontos jellemzó, hogy ez az étrend az étkezés alapját inkább a zöldségekre és a hüvelyesekre helyezi a húsfélék helyett, illetve kisebb arányú a tej és tejtermékek fogyasztása. Középpontjában a friss, szezonális ételek állnak, legtöbbször a halból vagy a tenger gyümölcseiből készült fogásokkal. A halak könnyen emészthető, teljes értékú fehérjéket, vitaminokat (D-, E-, B-vitaminok), ásványi anyagokat (kalcium, foszfor, vas, jód) tartalmaznak és ezek a legjobb forrásai az esszenciális omega-3 zsírsavaknak (RODLER 2006). Alkohol- és kalóriatartalma ellenére a mediterrán étrend engedélyezi a bor mérsékelt fogyasztását.

A US News megbízásából készült egy rangsor a táplálkozási szokásokat illetóen. 41 étrendet vizsgált meg egy 23 fóből álló egészségügyi szakember testület, akik 7 kategóriát vettek górcső alá: rövid- és hosszú távú súlycsökkenés, táplálkozástani érték, egészségesség, biztonság, beszerezhetőség, élvezhetőség. A vizsgálat alapján a mediterrán étrend kapta a 2019. év Legjobb Étrend díjat, megelőzve a DASH és a Flexitarian étrendeket. A DASH (Dietary Approaches to Stop Hypertension) táplálkozást a magas vérnyomás megelőzésére állították össze. Zöldségek, halak, szárnyasok, hüvelyesek fogyasztásán alapul, fontos eleme a megfelelő sótartalom fogyasztása, illetve kerüli az édességek és cukrozott italok fogyasztását. Azonban a mediterrán éttrenddel szemben a DASH táplálkozás engedélyezi a tej és tejtermékek fogyasztást, miközben gondosan ügyel a napi kalóriabevitelre. A Flexitarian táplálkozás a növényi

\footnotetext{
${ }^{4}$ https://www.sevencountriesstudy.com/about-the-study/
}

alapanyagok fogyasztására támaszkodik. Hasonlít a vegetáriánus táplálkozáshoz, de alkalmanként engedélyezi a húsfogyasztást. Az étrend követôi úgy étkeznek, hogy az elfogyasztott tápláléknak minél kisebb legyen az ökológiai lábnyoma, így hirdetve a környezeti fenntarthatóságot az étkezésben is (DELANEY 2017).

\subsection{A FENNTARTHATÓ ÉLELMISZER-FOGYASZTÁS}

A fenntartható élelmiszer-fogyasztásnak környezeti és egészségügyi vonatkozásai vannak, azonban nincs egységes, mindenki által elfogadott definíciója. Az mindegyik definícióban közös, hogy lényeges az egyéni cselekvés szerepe a fogyasztási alternatívák között való döntésnél, ezenkívül megjelenik a társadalmi (egészségügyi, jóléti) és a környezeti hatások együttese (VETÓNÉ 2014). Mivel az élelmiszer-fogyasztás közvetlen hatással van a fogyasztók egészségére, nem lehet attól elválasztva vizsgálni. A jelenlegi élelmiszer-fogyasztási szokások nem fenntarthatóak, mert nem csupán az eltartóképességet veszélyeztetik, hanem az emberi egészséget is. LEVETT és THERIVEL (2005) tanulmányai alapján az élelmiszer-fogyasztás akkor fenntartható, amennyiben az alábbi feltételek teljesülnek:

- biztonságos, egészséges és tápláló a boltokban, éttermekben, iskolákban, kórházakban hozzájutó fogyasztók számára;

- kielégíti a kevésbé tehetósek igényeit;

- életképes, megfeleló megélhetést biztosít a gazdálkodók, élelmiszer-feldolgozók és kiskereskedők számára, akiknek az alkalmazottai biztonságos és higiénikus munkakörülmények között dolgoznak országon belül és kívül egyaránt;

- a termelés és feldolgozás során tiszteletben tartják a biofizikai és környezeti határokat, miközben az energiafogyasztás csökkentésére és a környezet javítására törekszenek;

- az állatok egészségét és jóllétét a legnagyobb mértékben tiszteletben tartják, ami összeegyeztethetố azzal, hogy az egész társadalom számára megfizethetó élelmiszert termelnek;

- támogatja és tiszteletben tartja a vidéki gazdaságokat és a vidéki kultúra sokszínúségét, miközben kiemelten kezeli a helyi termékeket annak érdekében, hogy az élelmiszer minél rövidebb úton jusson el a termelőtól a fogyasztóhoz.

2019-ben az EU új irányelveket és határidőket fogalmazott meg a Közös Agrárpolitikájában (KAP), miszerint az állati eredetú termékek fogyasztását drasztikusan csökkenteni kell a 2019-2024 közötti 
időszakban, illetve 2030-ra meg kell valósítani a növényi alapanyagokon nyugvó fenntartható gazdálkodást (EVU 2019). Ennek elérése érdekében szoros együttmúködést javasolnak a tagállamok között a vegán, vegetáriánus életmód népszerúsítésére, előnyeinek széles körú terjesztésére, így a mediterrán táplálkozás is egyre inkább a fókuszba kerül. A mediterrán diétának sokkal alacsonyabb az ökológiai lábnyom értéke, kevesebb benne a hús, a kenyér és a tojás, viszont több a zöldség, a gyümölcs és szignifikánsan magasabb a hal fogyasztása (KSH 2013). TUKKER és szerzőtársainak tanulmánya (2011) alapján az úgynevezett mediterrán diéta elterjedése $10 \%$-kal csökkentené az üvegházhatású gázok kibocsátását, ami szintén ezen étkezési forma mellett szól.

\subsection{NARANCSBOROK}

A héjon erjesztett fehérborok készítési eljárása ősi hagyományokra nyúlik vissza. A mai Grúzia területén Kr.e. 6000 évvel kerámiaedényt ástak a földbe és ebbe helyezték el a szőlőt, amely levet eresztett és alkoholos itallá erjedt az egyenletes hőmérsékleten történő tárolás során. Az amfora formájú edényeket qvevrinek hívják és manapság is sok borász használja óket. A kvevri technológiát az UNESCO 2013-ban felvette az immateriális kulturális hagyományok között nyilvántartott eljárások sorába és azóta számos követőre talált, fóleg a Földközi-tenger térségében. A világ gasztronómiai trendként tekint rá, piacon való hosszú távú jelenléte azonban erôsen vitatott.

Korábbi kutatómunkánk során (BENEPISKÓTI 2017) összegyúijtöttük a narancsborok legfontosabb jellemzőit:

- szigorúan szóló alapanyagból készülő italkülönlegességek;

- megfelelnek napjaink gasztronómiai trendjének, mert a szőló alapanyag organikus gazdálkodásból származik, a borkészítés filozófiája visszanyúlik a hagyományokhoz, minimális a kénhasználat és nincsenek kémiai stabilizálószerek;

- kis ökológiai lábnyomú termékek, melyek a természetes borok készítési eljárásával készülnek, nem termelve környezetszennyező melléktermékeket;

- a készítésre vonatkozóan nincsenek konkrét szabályok megfogalmazva.

Az elmúlt évben - Zéta borokon végzett borkémiai vizsgálatok alapján - megállapítottuk, hogy a normál fehérborokhoz képest ezek a borok jóval magasabb mennyiségben tartalmaznak katechin vegyületeket, vagyis olyan polifenolokat, amelyek kedvezô élettani hatással rendelkeznek (májmúködés, ízületek, immunrendszer) (BENE 2018). Tannin tartalmuknak köszönhetően magas a természetes antioxidáns tartalmuk, így a narancsbor esetében segédanyagok nélkül is meggátolhatóak a borban zajló öregedési folyamatok, ezért nincs szükség kémiai szerekkel történő stabilizálásra (1. táblázat).

1. táblázat

Normál és kvevri borkészítési eljárással

készített Zéta borok kedvezó élettani hatású vegyületeinek összehasonlítása

\begin{tabular}{|c|c|c|}
\hline & $\begin{array}{c}\text { Narancs } \\
\text { Zéta }\end{array}$ & $\begin{array}{c}\text { Hagyományos } \\
\text { Zéta }\end{array}$ \\
\hline $\begin{array}{c}\text { Összes polifenol } \\
\text { tartalom }\left(\mathrm{mg}^{-1}\right)\end{array}$ & 1632 & 356 \\
\hline $\begin{array}{c}\text { TAS - Teljes } \\
\text { Antioxidáns Státusz } \\
\left(\text { mmol } l^{-1}\right)\end{array}$ & 12 & 6,76 \\
\hline $\begin{array}{c}\text { Procianidinek }\left(\mathrm{mg}^{-1}\right) \\
\text { Katechinek }\left(m g \mathrm{l}^{-1}\right)\end{array}$ & 1370 & 180 \\
\hline
\end{tabular}

Forrás: saját szerkesztés BENE (2018) alapján

\section{Módszertan}

Jelen munkánk során azt vizsgáltuk, hogy a mediterrán gasztronómiában hogyan tekintenek a narancsborokra, kik a fogyasztói, illetve hogy a gasztronómia szereplői megkülönböztetett figyelmet fordítanak-e rájuk. A fókuszcsoportos interjú módszerével dolgoztunk, amely kvalitatív piackutatási módszer. A fókuszcsoport egy olyan kiscsoportos találkozás, amelyet egy képzett csoportvezető, úgynevezett moderátor irányít. A fókuszcsoport egyedülálló a többi csoportmódszer között, mert nagyobb teret biztosít a csoporttagok közötti kölcsönös eszmecserének, véleményváltásnak (csoportinterakció), ezáltal jobban szemlélteti, hogy a tagok nézetei, meggyőződései miért éppen az adott formában alakultak. A cél a fókusz téma háttérinformációinak összegyújtése, új ötletek nyerése piacteremtés céljából (LEHOTA 2001).

$\mathrm{Az}$ általunk moderált fókuszcsoportos interjúra Bécsben került sor 2018. november 19-én, az Orange Wine Festival keretében rendezett konferencia alkalmával, 15 résztevővel. A helyszín és a résztvevők kiválasztásánál arra törekedtünk, hogy a három ország kiemelkedó gasztronómiai képviselőit szólítsuk meg, borkészítőket, séfeket és turisztikai szakmában dolgozókat, akik jártasak a 
Lektorált tanulmányok

narancsborok világában ${ }^{5}$. Az interjú megszervezésében a Bruno Zahar által vezetett orangewinefestival munkatársai nyújtottak segítséget.

\section{Eredmények}

Az interjú során az alábbi kérdéskörökre koncentráltunk:

- Hogyan lehet meghatározni a narancsbor fogalmát, tekintettel arra, hogy egyik országban sincs a narancsbor készítésére vonatkozó szabályzat?

- Mennyire tudatos a készítési eljárás, a borkészítési filozófia a borászok részéról?

- Mennyire jelennek meg a narancsborok az éttermi választékban?

- Milyen a kereslet ezekre a borokra a borászatoknál és az éttermekben?

- Lehet-e megkülönböztető szerepük egy helyi étel-ital specialitás létrehozatalában, ellátogatnának-e a turisták az adott desztinációba azért, hogy ebben az élményben részesüljenek?

A gasztronómiai szereplók szerint a narancsborokra úgy kell tekinteni, ahogyan az umamira, a négy alapízhez társult ötödik ízre. A narancsbor a három alapbor típushoz (fehér-rozé-vörös) csatlakozik negyedikként, tulajdonképpen nem önálló, hanem kiegészíti a többi bortípust, változó intenzitással jeleníti meg a három alapbor tulajdonságait. A borászok között van, aki úgy gondolja, hogy a rozé borok inverze, mert a rozé kékszólőből készül fehérbor készítési eljárással, míg a narancsbor fehérszőlőből készül vörösbor készítési technológiát követve. De van, aki a "természetes borok" ${ }^{\prime 6}$ kiemelkedó tagjaként látja. A narancsbor elnevezés nem a legmegfelelőbb, viszont a készítési eljárásra utal, hogy hosszú ideig történik a szőlóhéjjal való érintkezés, ezért mélyebb, borostyánosabb a színtónus. Az interjúalanyok inkább az amforabor megnevezést szeretik használni.

\footnotetext{
${ }^{5}$ Szlovénia: a Q-KOMEL Kobjeglava Restaurant képviselője, Andrej Erzetic (Erzetic Winery), Bruno Zaro (1348 Winery), Frank Vodopivec (Slavcek Winery), az I feel Slovenia tourinform iroda munkatársa. Horvátország: a Restaurant Badi képviselője, az Adriatic Shell képviselöje, a Zijavica étterem képviselöje, Daniel Bastijancic (Lunika Winery), a Love Istria tourinform iroda munkatársa. Olaszország: a Midolini Restauran képviselője, Dario Prinčič, Mitja Zahar (Zahar Winery), Guiseppe Amato (Val di Sole Cooperation), Italo Cescon Organic Winery.

${ }^{6} \mathrm{~A}$ természetes borok kategóriája hivatalosan nem létezik, a beavatkozásmentes technológiával készült borokat értjük alatta, ide tartoznak a biobiodinamikus-, organikus- és héjon erjesztett borok, amelyeknél elsődleges fontosságú a vegyszermentes szőlöművelés, a kézi szüret, a vadélesztők alkalmazása és a minimális vagy semmi kénhasználat (szerzői megjegyzés)
}

A készítési filozófiát tekintve a narancsborokat nem a világfajtákból állítják elő, hanem a tradicionális, autochton, az adott bortermő régióra jellemzô szőlőfajtákból: Malvazija, Belo, Refošk, Ribolla, Rebula (Szlovénia), Trebež, Teran (Horvátország), Jakot, Trebbiano, Vermentino (Olaszország). Általában családi borászatok készítik, akik nem feltétlenül kisebb területen gazdálkodnak, viszont régóta, évszázados családi hagyományok révén apáról fiúra örökítik a szőloó- és borkészítés tudományát: Erzetic Winery (1725), Zaro (1348!), Slavcek (1769). A szlovén, a horvát és az olasz borkészítők amforaborai a mindennapjaik természetes velejárói. Nem trendként vagy különlegesként tekintenek rájuk, hanem a föld, az Isten és az ember találkozásának velejárója. Nem versenyelőny, hanem az életmódjuk egyfajta önkifejezése. A grúziai Kakheti régióban az Alaverdi kolostor elvei szerint olyan bort kell készíteni, hogy „elég jó legyen Isten számára”. A szerzetesek szemében értéktelenek azok a borok, amelyekbe adalékanyagokat és ként tesznek, ezt a filozófiát vallják amforaboruk készítése során is. Kiemelték, hogy a tradíció, a gyökerek tiszteletben tartása nagyon fontos küldetésük, de kapcsolódik hozzá innováció is, hiszen szép, különleges megjelenéssel kerülnek a piacra, fóként a helyi éttermekbe. Ezen túlmenóen saját értékesítés útján juttatják el a bort a fogyasztókhoz, áruházi, bolti értékesítésük nincs.

A fókuszcsoportban jelen lévő szlovén és horvát gasztronómiai szakemberek éttermi kínálatukban inkább az ételkülönlegességekre fókuszálnak, mindamellett fontos számukra, hogy legyen bóséges borválaszték, kizárólag helyi és természetes borokból. Nem tartják számon külön kategóriaként az amforaborokat. A szlovén Kobjeglava étterem séfje nyilatkozott úgy, hogy ók fóként a Kras szárított sonkakészítményekre fókuszálnak, melyekhez színben és fanyar, citrusos ízeivel kiváló harmóniát nyújtanak a narancsborok. Ezért tartják ezeket a borokat az italválasztékukban, de nem narancsborként, hanem héjon erjesztett fehérbor-különlegességként. Az olasz gasztronómia mindig nagy figyelmet szentel az italoknak, különösen a boroknak, így számukra természetes, hogy a narancsborok szerepelnek a választékban. Nem negyedik bortípusként, hanem az úgynevezett authentic naked wine (meztelen borok) csoportban, amely nélkülözi mindenféle borkezelési segédanyag, eljárás alkalmazását és kizárólag vegyszermentes alapanyagot használ.

A tudatos borfogyasztók, a gasztronómiai sznobok, a gourmet fogyasztók keresik azokat a helyeket a világban, ahol nem akarják másnak mutatni a dolgokat, ahol nem akarják becsapni óket, hanem tisztán, a maga eredeti valóságában 
részesülhetnek az élményben. Ilyen a mediterrán térség is, hiszen az itt készített gasztronómiai termékekben a biztonságot, a frissességet, a szakértelmet, a vegyszermentességet, az egészséget és nem utolsó sorban az élvezetet látják, így szívesen választják ezeket a borokat az éttermi kínálatból. A borászokhoz érkező turisták nem az amforabor miatt érkeznek, hanem a vegyszermentes gazdálkodás, a természettel való kapcsolat megnyilvánulása miatt és váratlan élményben részesülnek, amikor bevezetik őket a földbe ásott kerámiaedények világába. A több olasz borászatot tömörítő Piemont Borrégió Val di Sole Szövetkezet alapítója, Guiseppe Amato szerint mindig a hagyományos borkészítés és a természetesség filozófiáját tartják szem előtt. A narancsbor készítési eljárás ennek innovatív tükröződése, múvészeti tökéletesség, amelyet minél több embernek meg kellene ismernie, de jelenleg kevesen érdeklődnek az amforaborok és általában a beavatkozásmentes borok iránt. Ezért nagyon fontos szerepe lenne az ismeretterjesztésnek, ami egyelőre nem elég hatékony.

Fontos kiemelni, hogy az étel-ital párosításnál bármit elképzelhetőnek tartanak, de helyi alapanyagnak kell lennie, ami bármikor rendelkezésre áll, és frissnek kell lennie. Mivel az ízvilág nagyon gazdag skálán mozog, hisz az elsődleges szőlő aromajegyek mellett tanninos, fanyar ízek is megjelennek és mindig feltúnik a gyógynövényes jelleg, így izgalmas feladat ételt párosítani hozzájuk. A különböző tengeri halak (brancin, orada, oslic, aranydurbincs, tengeri sügér, tókehal, lazac, tonhal, ördöghal, szardella, márna, Szent Péter hala/kakashal) és a szárított sonkakészítmények, a friss zöldségek, az érlelt sajtok bármikor kínálhatóak a narancsborok mellé, és együtt fogyasztva multiszenzorális élményben részesül a vendég. A szlovének a korábban említett Kras sonka mellé képzelik el, de az olasz pármai sonka mellé is kiváló lehet, amely kevésbé sós és lágyabb. A balzsamecettel átitatott olívás baguette-tel amuse bouchénak is értelmezhető, hisz az eredetjelleg, a termőterülettel való kapcsolat egyedivé és felejthetetlenné teheti a megjelenő ízélményt. A horvát Adriatic Shell étterem friss tonhal steakhez ajánlja, amely helyi zöldségekkel és friss fúszerekkel készül, de pesto és tengeri sügér alapanyagú ételkombinációt is szívesen kínál melléjük (3. ábra). Ezeket az ételeket is ajánlani kell azonban, mert maguktól ritkán választják a betérô vendégek, vagyis az adott helyre nem ezért látogatnak el, ugyanakkor másodlagos célként megjelenhetnek, ha a turista már megérkezett az adott desztinációba és helyi különlegességet szeretne kóstolni.
A pesto és tengeri sügér találkozásából

3. ábra készített narancsbor kísérő

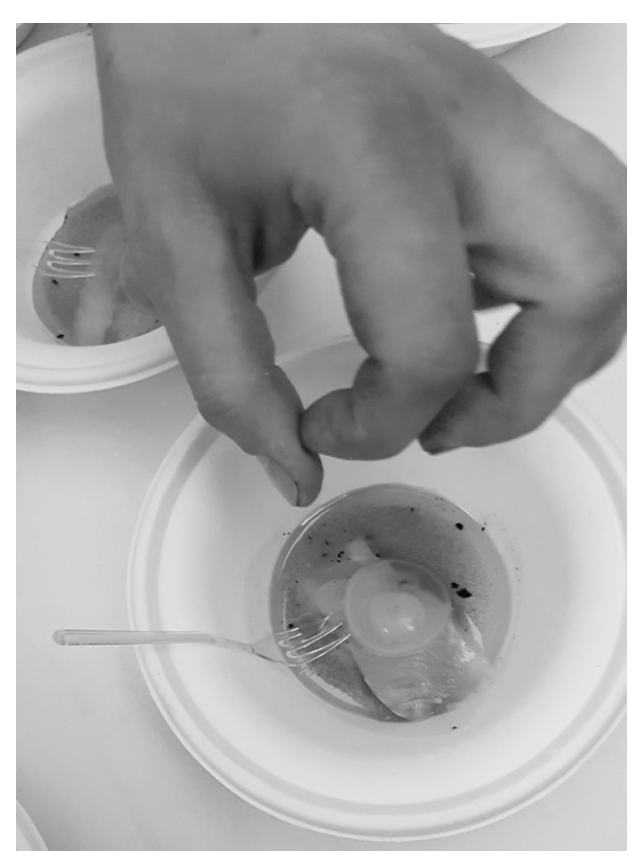

Forrás: saját felvétel

\section{Következtetések}

A fókuszcsoportos interjú megerősített olyan feltevéseket, amelyeket a korábbi kutatásaink során is megfogalmaztunk, miszerint a héjon erjesztett fehérborok a természetes borok kategóriájába tartozó termékek. Azok a borok, ahol a készítés során nem követik ezt az eljárást, nem felelnek meg a narancsborkészítés íratlan szabályainak. A technológia ősi hagyományokon alapul, ezért is célszerú ott keresni ezeket a borokat, ahol készítőik nagy figyelmet szentelnek ennek. A borkészítési folyamat szakértelmet és tudatosságot kíván, nem lehet bizonytalan próbálkozásokra utólagosan rámondani, hogy azért lett olyan, amilyen, mert készítője a természetre bízta a bor sorsát.

Az interjún részt vett személyek-Horvátország, Szlovénia, Olaszország gasztronómiai képviselói - ismerik a narancsborokat, vagy készítik, vagy dolgoznak velük. Fontosnak tartják, egyfajta választékbővítésnek, ugyanakkor nem társítanak hozzájuk megkülönböztető szerepet, nem emelik ki óket a sorból kulináris trendként vagy különlegességként. A narancsbor nem kerül előtérbe egészségtudatosság szempontjából sem, mert a termék felé természetes mivolta révén bizalommal fordulnak, hisz az összes alapanyag, amelyet a készítés során alkalmaznak, egészséges. 
Lektorált tanulmányok

Az idegenforgalom szempontjából a térség országai nem jelennek meg együtt, egységesen, nem erősítik egymás turizmusát sem a közös értékek, sem a helyi adottságok bemutatásával. A helyi értékek, az egyes sajátosságok jobban meg tudnának jelenni, ha a narancsbor esetében is megmutatnák, hogy a mediterrán borkészítók milyen filozófiával készítik azokat, és hogy az mennyire eltér a világ egyéb tájain alkalmazott elvektól. Így az egyes nemzetek különállók maradnak, nem generálódik figyelem a közös értékteremtésre.

Fontos lenne közös marketingtevékenységet kialakítaniuk, hangsúlyozva a narancsbor egészségmegőrző tulajdonságát, tradicionális készítési eljárását és a környezeti fenntarthatóságban betöltött szerepét. A héjon erjesztett borkészítési eljárás bölcsője Grúzia, de a Földközi-tenger egyes országaiban is - az országra jellemző szólófajtákat használva - követik ezt a technológiát. A földbe ásott agyagedények látványa olyan varázslatos világot teremt, amellyel csak az adott térség meglátogatásakor lehet találkozni. Vannak olyan országok is (például Magyarország, Ausztria, Románia), ahol modern eszközökkel (spin-hordó, betontojás), világfajtákat alkalmazva, az egészség- és környezettudatosságot kihangsúlyozva készítenek narancsborokat.

Meg kell jegyeznünk továbbá, hogy a narancsborra fókuszáló gasztronómiai rendezvény helyszíne Bécs, és nem a Mediterráneum. Inkább elmennek máshol kiállítani, mintsem maguk szerveznének saját fesztivált autentikus környezetben, a gasztroturizmus nyújtotta lehetóségeket kihasználva. Ezeknek a boroknak nem az áruházak, a borkereskedések az értékesítési helyszínei, hanem a HORECA (HOtel/REstauramt/CAfé) szektor és a helyi értékesítés, így nem elutazniuk kellene a háttér megmutatása nélkül, hanem magukhoz kellene vonzani a turistákat.

A borra, a sajtokra, az olajra, a sonkára és a tengeri halakra fókuszáló gasztroturizmus kiemelkedően fontos ágazat a mediterrán térség országaiban. A mediterrán étkezési szokás olyan összetett szellemi örökség, melynek fontos elemei a friss, helyi alapanyag-használat, az egészséges és élelmiszerbiztonság szempontjából minőségi termékek készítése és fogyasztása, valamint a természet szeretete és a borhoz való kötődés. A narancsborkészítés filozófiája szépen belesimul ebbe, de szerepe nem központi, noha az iránta tanúsított növekvő figyelem révén a mediterrán gasztrokultúra fontos eleme lehetne. A térség borászai a világ egyéb tájaitól eltérően, kizárólag az őshonos, helyi szőlőfajtákból készítenek ilyen eljárással bort, így ezen fajták fennmaradásában és új életre keltésében rendkívül fontos szerepet játszanak. Nem az új kulináris élmény fogja a turizmust előremozdítani, hanem az étel-ital készítóje és az ősi, helyi ízek iránti megismerési vágy. A storytelling nagy segítség lenne abban, hogy az adott térségbe látogató vendég tudatosan keresse ezeket az értékeket, hajlandó legyen elutazni értük. Hogy a Dolomitok olasz narancsboraitól kezdve úgy jusson el a dalmáciai borostyánsárga amforákig, hogy közben betekintést nyer az egyes régiók kulináris világába, és átérezheti azt a közös szándékot, amelyet ezek a borok közvetítenek az ősi, perifériára szorult készítési eljárásuk újraélesztése révén. A teljeskörú elemzéshez azonban mindenképpen szükséges a fogyasztói oldal megkérdezése is, így a késóbbiekben a keresleti oldal vizsgálatával folytatjuk munkánkat.

\section{Felhasznált irodalom}

BENE ZS. (2018): A qvevri borkészítési eljárás és a narancsborok létjogosultsága a gasztronómiai újdonságok körében. In: Dankó L. (szerk.): Narancsbor: Fejezetek a gasztronómiai újdonságok témaköréból. Tokajbor-Bene Pincészet, Szőlőbirtok és Borkereskedelmi Kft., Bodrogkeresztúr. pp. 9-17.

BENE ZS.- PISKÓTI I. (2017): A narancsborok megítélése az új élelmiszer-fogyasztási trendek tükrében. Élelmiszervizsgálati közlemények. 63(4). pp. 1790-1811.

GUZEL, B. - APAYDIN, M. (2017): Gastronomy Tourism: Motivations and Destinations. In: Avcikurt, C. - Dinu, M. S. - Hacioǧlu, N. - Efe, R. - Soykan, A. - Tetik, N. (eds): Global Issues and Trends in Tourism. pp. 394-404.

HARRINGTON, R. J. (2005): Defining Gastronomic Identity: The Impact of Environment and Culture on Prevailing Components, Texture and Flavors in Wine and Food. Journal of Culinary Science E Technology. 4(2/3). pp. 129-152.

HJALAGER, A-M. - RICHARDS, G. (2001): Still undigested: research issues in tourism and gastronomy. In: Hjalager, A-M. - Richards, G. (eds): Tourism and gastronomy. Routledge, London. pp. 224-234.

KÖNYVES E. - VARGÁNÉ CSOBÁN K. (2015): Gasztronómia és turizmus. Elméleti jegyzet. Debreceni Egyetem. pp. 95-112.

KSH (2013): A haltermelés és -fogyasztás alakulása a világon és Magyarországon. Statisztikai tükör. 7(84). pp. 1-4.

LEHOTA J. (2001): Marketingkutatás az agrárgazdaságban. Mezőgazda Kiadó.

RODLER I. (2006): Mediterrán táplálkozás Mediterrán étrend. Medicina Könyvkiadó, Budapest. 
TIKKANEN, I. (2007): Maslow's hierarchy and food tourism in Finland: five cases. British Food Journal. 109(9). pp. 721-734.

TUKKER, A. - GOLDBOHM, R. A. - de KONING, A. - VERHEIJDEN, M. - KLEIJN, R. - WOLF, O. - PÉREZ-DOMÍNGUEZ, I. - RUEDACANTUCHE, J. M. (2011): Environmental impacts of changes to healthier diets in Europe. Ecological Economics. 70(10). pp. 1776-1788.

VETŐNE M. ZS. (2014): Fenntartható élelmiszerfogyasztás? - Lehetóségek az ökológiai lábnyom csökkentésére a magyar lakosság körében. Vezetéstudomány. 45(7-8). pp. 2-14.

WILLIAMS, H. A. - WILLIAMS, R. L. Jr. - OMAR, M. (2014): Gastro-tourism as destination branding in emerging markets. International Journal of Leisure and Tourism Marketing. 4(1). pp. 1-18.

\section{Internetes források}

BARCELONA FIELD STUDIES CENTRE (2012): Food or Gastronomic Tourism an Rural Development. http://geographyfieldwork.com/ FoodTourism.htm, Letöltve: 2019. június 7.

BONNÉ, J. (2018): The Insider's guide to Orange Wine. https://punchdrink.com/articles/insidersguide-best-orange-wine/, Letöltve: 2019. április 9.

COPPOLA, M. E. (2016): Food, Tourism and Culture: The keys to success of a global trend. https:// www.trekksoft.com/en/blog/food-tourism- culture-keys-success-global-trend, Letöltve: 2019. június 7.

DELANEY, E (2017): What is a flexitarian diet? https://www.bbcgoodfood.com/howto/ guide/what-flexitarian-diet, Letöltve: 2019. január 28.

EVU (European Vegetarian Union) (2019): Three Pillars for a Sustainable European Food System. https://www.euroveg.eu/wp-content/ uploads/2019/05/EVU_-Three-Pillars-for-aSustainable-European-Food-System_final.pdf, Letöltve: 2019. június 7.

LEVETT-THERIVEL (2005): Sustainability implications of the little red tractor scheme. Report for the Sustainable Development Commission. London. http://www.sd-commission.org. uk/data/files/publications/050119\%20 Sustainability\%20implications $\% 20$ of $\% 20$ the $\% 20$ Little\%20Red\%20Tractor\%20scheme.pdf, Letöltve: 2019. január 28.

MTÜ (2019): Turisztikai termékek/Bor és gasztroturizmus. https://mtu.gov.hu/cikkek/ bor-es-gasztroturizmus, Letöltve: 2019.június 7.

SZENDE G. (2018): $A z$ étrend, amely a világörökség része. http://www.origo.hu/ tafelspicc/20180906-mediterran-etrend.html, Letöltve: 2019. január 28.

UNWTO (2012): Annual Report. http://www2. unwto.org/publication/unwto-annualreport-2012, Letöltve: 2019. április 10.

UNWTO (2018): UNWTO Tourism Highlights: 2018 Edition. https://doi.org/10.18111/9789284419876, Letöltve: 2019. április 10. 